University of Nebraska - Lincoln

DigitalCommons@University of Nebraska - Lincoln

Biological Systems Engineering: Papers and

Publications

Biological Systems Engineering

2013

\title{
Seepage-Induced Streambank Erosion and Instability: In Situ Constant-Head Experiments
}

\author{
T. L. Midgley \\ Oklahoma State University - Main Campus, taber.midgley@okstate.edu
}

G. A. Fox

Oklahoma State University - Main Campus, gafox2@ncsu.edu

G. V. Wilson

USDA-ARS, glenn.wilson@ars.usda.gov

D. M. Heeren

University of Nebraska-Lincoln, derek.heeren@unl.edu

E. J. Langendoen

USDA-ARS National Sedimentation Laboratory, eddy.langendoen@ars.usda.gov

See next page for additional authors

Follow this and additional works at: https://digitalcommons.unl.edu/biosysengfacpub

Midgley, T. L.; Fox, G. A.; Wilson, G. V.; Heeren, D. M.; Langendoen, E. J.; and A. Simon, "Seepage-Induced Streambank Erosion and Instability: In Situ Constant-Head Experiments" (2013). Biological Systems Engineering: Papers and Publications. 303.

https://digitalcommons.unl.edu/biosysengfacpub/303

This Article is brought to you for free and open access by the Biological Systems Engineering at DigitalCommons@University of Nebraska - Lincoln. It has been accepted for inclusion in Biological Systems Engineering: Papers and Publications by an authorized administrator of DigitalCommons@University of Nebraska Lincoln. 


\section{Authors}

T. L. Midgley, G. A. Fox, G. V. Wilson, D. M. Heeren, E. J. Langendoen, and A. Simon 


\title{
Seepage-Induced Streambank Erosion and Instability: In Situ Constant-Head Experiments
}

\author{
T. L. Midgley ${ }^{1}$; G. A. Fox, P.E., M.ASCE${ }^{2}$; G. V. Wilson ${ }^{3}$; D. M. Heeren, P.E., M.ASCE${ }^{4}$; \\ E. J. Langendoen, M.ASCE${ }^{5}$; and A. Simon ${ }^{6}$
}

\begin{abstract}
The effects of seepage on streambank erosion and failure are less understood compared to fluvial processes, especially the linkage between surface water and groundwater mechanisms. Field data are needed to validate laboratory seepage erosion and instability conclusions and to understand how engineering tools and methods may be applied to field conditions. An innovative trench injection system was utilized to provide a constant head on a near-streambank groundwater system when filled with stream water. This research was performed on a streambank of Dry Creek, a deeply incised stream with near-vertical banks located in Mississippi. Experiments included installing a trench ( $2.8 \mathrm{~m}$ from the bank and $2 \mathrm{~m}$ below ground surface) and a network of tensiometers and observation wells to measure soil-water pressures and water table elevations. Bank stratigraphy consisted of a sloping, conductive loamy sand layer between cohesive streambank layers. Groundwater conditions were monitored during a series of induced-seepage experiments. The bank face was outfitted with a seepage collection device to measure seep flow rates and sediment concentrations. Seepage flow rates (as high as $0.4 \mathrm{~L} / \mathrm{min}$ ) and corresponding erosion rates (as high as $0.86 \mathrm{~kg} / \mathrm{min}$ ) were proportional to estimated hydraulic gradients in the near-streambank region and followed an excess flow rate equation. However, flow paths and hydraulic gradients were largely nonuniform due to local variability in streambank stratigraphy, suggesting difficulty when attempting to apply engineering analyses of bank erosion and stability for seepage processes without accounting for this heterogeneity. Seepage flow and erosion became restricted when small-scale bank failures due to undercutting blocked flow pathways and limited particle mobilization, termed temporary self-healing. Seepage erosion was shown to be an important mechanism of streambank failure, especially when acting in concert with fluvial erosion processes that prevent permanent self-healing of seeps. DOI: 10.1061/(ASCE) HE.1943-5584.0000685. (C) 2013 American Society of Civil Engineers.
\end{abstract}

CE Database subject headings: Seepage; River bank erosion; Subsurface flow; Experimentation.

Author keywords: Seepage erosion; Streambank erosion; Streambank failure; Streambank stability; Subsurface flow; Surface/groundwater interaction.

\section{Introduction}

Bank erosion has been largely neglected in quantifying sediment yield in watersheds until the 1970s (Lawler et al. 1997) but may

${ }^{1}$ National Science Foundation Graduate Fellow, Dept. of Biosystems and Agricultural Engineering, Oklahoma State Univ., Stillwater, OK 74078. E-mail: taber.midgley@okstate.edu

${ }^{2}$ Professor and Orville L. and Helen L. Buchanan Chair, Dept. of Biosystems and Agricultural Engineering, Oklahoma State Univ., $120 \mathrm{Ag}$ Hall, Stillwater, OK 74078-6016 (corresponding author). E-mail: garey.fox@ okstate.edu

${ }^{3}$ Soil Physicist/Hydrologist, USDA-ARS National Sedimentation Laboratory, 598 McElroy Rd., Oxford, MS 38655. E-mail: glenn.wilson@ ars.usda.gov

${ }^{4}$ Assistant Professor, Biological Systems Engineering, Univ. of Nebraska, Lincoln, NE 68583; formerly, Research Engineer and U.S. EPA STAR Fellow, Dept. of Biosystems and Agricultural Engineering, Oklahoma State Univ., Stillwater, OK 74078. E-mail: Derek.heeren@okstate.edu

${ }^{5}$ Hydraulic Engineer, USDA-ARS National Sedimentation Laboratory, 598 McElroy Rd., Oxford, MS 38655. E-mail: eddy.langendoen@ars.usda .gov

${ }^{6}$ Geomorphologist, Cardo-Entrix, 5415 SW Westgate Dr., Portland, OR 97221. E-mail: andrew.simon@ cardno.com

Note. This manuscript was submitted on November 10, 2011; approved on July 5, 2012; published online on August 6, 2012. Discussion period open until March 1, 2014; separate discussions must be submitted for individual papers. This paper is part of the Journal of Hydrologic Engineering, Vol. 18, No. 10, October 1, 2013. (C) ASCE, ISSN 1084-0699/ 2013/10-1200-1210/\$25.00. be the source of a majority of sediment yield in some watersheds (Wilson et al. 2008). There is now a considerable volume of literature (e.g., Simon and Darby 1999; Sekely et al. 2002; Evans et al. 2006) that addresses the relative importance of streambank sources as a component of watershed sediment yield. Two mechanisms are typically credited for the bulk of streambank erosion: fluvial erosion and mass wasting due to bank instability with multiple interrelated processes (ASCE 1998; Simon et al. 2000). One mechanism of both bank erosion and geotechnical instability that has received less attention historically is subsurface flow, which may be equally important in some cases to more commonly observed fluvial mechanisms, but is most frequently neglected or overlooked (Hagerty 1991; Fox et al. 2007; Wilson et al. 2007). Subsurface flow can cause erosion and bank instability through several specific mechanisms: soil-water pressure, seepage gradient forces, and seepage erosion (Chu-Agor et al. 2008a; Fox and Wilson 2010).

First, when water enters the bank from either infiltration of precipitation on the landscape or bank storage during high stream stage, soil-water pressures increase reducing the soil's apparent cohesion (Fredlund and Rahardjo 1993; Fox and Wilson 2010). This process also adds weight to the soil block, increasing the driving forces. Rinaldi et al. (2004) studied the effects of soil-water pressure on bank stability for four years on the Sieve River in Italy. They found that even without fluvial undercutting, a slight decrease in apparent cohesion due to soil-water pressure was enough to cause bank failure. Second, Iverson and Major (1986) noted that 
a seepage force vector is responsible for destabilizing hillslopes subjected to subsurface flow and claimed seepage forces played a bigger role on slope destabilization than excess soil-water pressures. They found that stability of hillslopes subjected to seepage depend on three factors: the ratio of the seepage force magnitude to gravitational force magnitude, the angle $\theta-\varphi$ where $\theta$ is the bank angle and $\varphi$ is the internal angle of friction, and the angle $\lambda-\varphi$ where $\lambda$ is the seepage vector angle measured from the surface normal vector. This mechanism can cause geotechnical failure or liquefaction, the complete loss of shear strength in the soil (Fox and Wilson 2010).

For failure to occur, the hydraulic gradient of the seepage must be substantial enough to overcome all resisting forces acting on the soil particles, such as interlocking, interparticle friction; cohesion; cementation; binding by roots; and gravity (Hagerty 1991). These types of failures are often referred to as pop out or tension failures. Lobkovsky et al. (2004) showed that seepage force is proportional to the hydraulic gradient with the following relationship:

$$
\mathrm{SF}=\rho g \frac{\partial h}{\partial y}
$$

where SF = seepage force per unit volume of soil; $\rho=$ fluid density; $g=$ acceleration due to gravity; $h=$ hydraulic head; and $y=$ distance over which $h$ acts. Chu-Agor et al. (2008a) conducted laboratory experiments in order to analyze this type of erosion. They found that if the soil was weak, i.e., the soil resistive forces cannot withstand the seepage gradient forces, a pop out failure occurred.

Wilson et al. (2007) and Fox et al. (2007) noted that seepage erosion, i.e., mobilization of particles entrained in the seepage exfiltrating a bank face, was causing undercutting of deeply incised streambanks in Mississippi. Hagerty et al. (1981) made similar observations along the Ohio River and termed this process internal erosion, while others (Richards and Reddy 2007) use the term backwards erosion. In contrast, internal erosion is almost always associated with the erosion of the inside walls of a preferential flow paths, e.g., macropores or soil pipes (Fox and Wilson 2010; Wilson et al. 2013). Seepage erosion is generally attributed to layers of contrasting hydraulic properties within the banks and terraces in which a less-permeable layer causes lateral flow through a more conductive, often noncohesive, layer above. Water flowing through the higher hydraulic conductivity layer causes seepage erosion, or particle entrainment, at the bank face. Fox et al. (2007) proposed an excess flow rate relationship between seepage flow rate and erosion rate

$$
E_{r}=k_{s}\left(q-q_{c}\right)^{a}
$$

where $E_{r}=$ erosion rate $(\mathrm{g} / \mathrm{min}) ; k_{s}=$ seepage erosion rate coefficient; $q=$ seep flow rate $(\mathrm{L} / \mathrm{min}) ; q_{c}=$ critical seep flow rate $(\mathrm{L} / \mathrm{min})$; and $a$ is power term assumed unity. An undercut develops as the noncohesive layer erodes away and eventually the overlying cohesive layers fail (Hagerty et al. 1981; Fox et al. 2007). This process was attributed by Hagerty et al. (1981) to be one of the dominate mechanisms causing bank retreat on the Ohio River, particularly during time periods with high precipitation.

Previous studies have focused on the seepage-erosion particlemobilization process in the laboratory under well-controlled conditions. Rulon et al. (1985) developed and validated a finite element model for analyzing groundwater seepage in a hillslope with impeding (lower hydraulic conductivity) layers. Flow was modeled as steady state, variably-saturated flow through a two-dimensional heterogeneous region. This model was validated with a laboratory experiment using a plexiglass sand tank filled with medium sand using fine sand as the impeding layer. Inflow into the physical model was accomplished by a rainfall simulator. The physical and finite element models demonstrated that concentrated exfiltration would occur just above the impeding layer. The exfiltration strongly depended on the position of the impeding layer and the hydraulic conductivity ratio. Chu-Agor et al. (2008a) conducted multiple laboratory experiments observing seepage erosion undercutting and found that when the bank could resist the seepage gradient forces and the seepage was concentrated, particle mobilization was initiated. Development and size of the undercut depended on the bulk density of the soil, which influenced hydraulic conductivity, cohesion, internal angle of friction, and critical hydraulic gradients to induce seepage particle mobilization. Chu-Agor et al. (2008b) demonstrated that a stable bank could quickly become unstable due to seepage erosion undercutting, leading to bank failure.

Seepage erosion is difficult to recognize as an active factor in bank erosion for many reasons. Hagerty (1991) and Fox and Wilson (2010) list several: seepage erosion is subtle; seepage erosion is intermittent; seepage erosion is a very complex mechanism, and many different conditions can cause substantial seepage erosion after one storm event, but negligible erosion after a different storm event; undercutting of streambanks may be misinterpreted as resulting from fluvial erosion; and concurrent bank erosion mechanisms may hide evidence of seepage erosion. For example, bank collapse can hide evidence of earlier undercutting and/or cover the original seepage face with failed material. Hagerty (1991) recognized that even with substantial research, computer models, and laboratory experiments on the effects of seepage erosion, there was a lack of application and understanding of seepage processes.

Therefore, the objectives of this research were to investigate particle mobilization and local failure mechanisms of seepage erosion under controlled field conditions and to understand how engineering tools and methods recently developed for seepage erosion processes may be applied to such field conditions. This research utilized an innovative trench injection system in the field to induce a constant head upon the streambank. The goal of this research was to also investigate whether or not previously proposed excess flow rate relationships can be extended to unique soil conditions.

\section{Materials and Methods}

\section{Field Site and Site Characterization}

Dry Creek $\left(33^{\circ} 44^{\prime} 54.6^{\prime \prime} \mathrm{N}, 89^{\circ} 10^{\prime} 20.8^{\prime \prime} \mathrm{W}\right)$, located in Chickasaw County, Mississippi, is a tributary to Little Topashaw Creek (LTC), a $37 \mathrm{~km}^{2}$ experimental subwatershed of the Topashaw Canal CEAP watershed in Mississippi (Wilson et al. 2008). Evidence of seepage erosion was noticed at several locations along Dry Creek and LTC in the form of undercutting and depositional/flow patterns in the soil. This creek is a deeply incised stream, with near- $90^{\circ}$ banks, that flows through alluvial plains under cultivation that are surrounded by forested areas. Excess sediment has been identified as the main water quality issue in the watershed with gullies and banks being the main sources (Wilson et al. 2008). A site survey of Dry Creek was conducted using total station equipment and known monuments established from previous studies. Elevations above sea level of relevant locations are indicated in Fig. 1. The strongest evidence of seepage was located approximately 3.0 to $3.5 \mathrm{~m}$ below the top bank while the baseflow water elevation was located $6.5 \mathrm{~m}$ below top bank.

Prior to any experiments or detailed measurements, the authors observed that a sand layer occurred on the bank face between more cohesive soil layers with greater clay content. However, the sand 


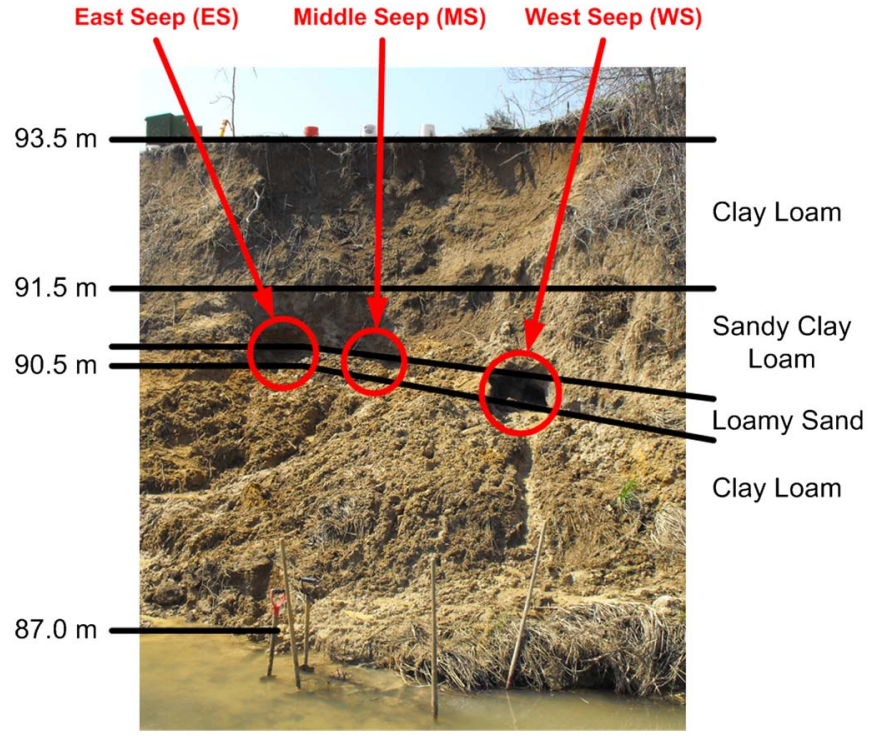

Fig. 1. Dry Creek bank stratigraphy and locations and naming conventions of seeps observed during the induced-seepage experiments

layer was covered by deposited cohesive material from previous bank failures. This cohesive soil capped the sandy layer, preventing seepage erosion undercutting prior to the study period and no highstage events occurred immediately prior to or during the study to remove the material by fluvial erosion. In fact, stream discharge was just above baseflow levels due to recent precipitation events prior to the constant-head seepage experiments. Before this material was removed, seepage was observed when a high water table provided enough head to drive seepage through this material. When natural high water table events caused seepage through the toe, erosion was limited by the cohesive nature of the deposited soil. Once the cohesive material of the upper toe was manually removed for the experiments, seepage erosion of the exposed sand layer began immediately.

Soil property measurements were acquired to quantify soil properties and strength parameters. Soil samples were collected from various depths on the bank face and trench for conducting particle size analyses. Borehole shear tests (BST) were conducted at various depths in the soil profile using an Iowa Borehole Shear Test (Handy Geotechnical Instruments Inc., Madrid, Iowa) Model A104.2 (Simon 1995; Soenksen et al. 2003). Tests were conducted at three different locations and six different depths $(1.0,1.5,2.0,2.5,3.0$, and $4.0 \mathrm{~m}$ depths). Tests consisted of boring a $5.7-\mathrm{cm}$-diameter hole to the desired depth and inserting the BST shear head. The shear head was attached to a dynamometer by a pull rod. $\mathrm{CO}_{2}$ was used to pressurize the shear head against the sides of the bore hole (normal stress). A crank was used to apply upward pressure on the shear head (shear stress) until failure. The normal stress and corresponding shear stress at failure was plotted to create the failure envelope. The test was repeated at four increasing normal stresses at each depth to derive the apparent cohesion and internal angle of friction. Matric suction data from the tensiometer network were used to estimate an effective cohesion and effective internal angle of friction.

\section{Site Installation and Setup}

Site setup included installation of an injection trench, observation wells, and tensiometers. The trench was installed $2.8 \mathrm{~m}$ from the nearest point on the bank with a length of $2.4 \mathrm{~m}$, a width of $0.6 \mathrm{~m}$, and depth of $2 \mathrm{~m}$ (Fig. 2). A wood frame was constructed with plywood walls (open on the bottom) and inserted into the trench (Fig. 2). The plywood on the stream side of the frame had a pattern of holes drilled through it in order to allow infiltration into the soil profile. Gravel filled the bottom 25 to $30 \mathrm{~cm}$ of the trench and around the outside of the bank side of the frame.

Nine wells were installed at two depths $(2 \mathrm{~m}$ and $4.3 \mathrm{~m})$. The wells were screened for $1 \mathrm{~m}$ from the bottom of the wells with solid casing above. Wells were installed in three columns (perpendicular to the streambank) from the trench to the bank edge (Fig. 3). Each well was equipped with an Onset Hobo Data logger (Onset, Bourne, Massachusetts) for recording water depth and temperature. Sixteen UMS T4 tensiometers (UMS, Munich, Germany) were installed between the trench and the bank edge at multiple depths (Fig. 3). Additionally, six $0.30 \mathrm{~m}$ T5 tensiometers were installed into the bank face at multiple elevations below the top bank. As shown in Fig. 3, the tensiometers are referred to by their row (parallel to the streambank, i.e., trench, middle, bank, or face), then their column (west, middle, or east), and finally their depth in $\mathrm{m}$. For example, BM25 refers to the T4 tensiometer in the row nearest the bank, middle column, at $0.25 \mathrm{~m}$ depth.

\section{Seepage Collection and Flow Rate Measurement System}

In order to collect data on seep flow and erosion rates, a system was designed to collect flow and eroded soil from a localized seep. Several seepage collection pans were constructed of varying widths. A pan was driven into the bank below the seepage location and secured. The pan routed seepage and entrained particles to a PVC pipe which led the seepage down the bank to collection vessels. Two methods were used to obtain flow and erosion rate measurements. For high-flow seeps, a 5 gal. (18.9 L) bucket was placed at the end of the PVC pipe. This bucket was allowed to fill for a set amount of time, at the end of which the bucket was weighed. Finally, the contents of the bucket were manually stirred to evenly distribute all sediment in the water and a representative sample taken for quantifying sediment concentrations. Flow and erosion rates were derived using the weights of the buckets plus the sediment concentrations. For low flow rate seeps, a small sample bottle collected the seepage from the end of the PVC pipe after which the entire sample was taken to the lab for flow and erosion rate determination.

\section{Seepage Experiments}

The trench was filled and allowed to drain on March 15, 2011, and March 16, 2011, as the goal was to prewet the bank to facilitate seepage once experiments started. Precipitation events occurred several days prior to introducing water into the trench including 1.3, 2.2, 1.7, 1.1, and $2.4 \mathrm{~cm}$ on March 4, March 5, March 8, March 9, and March 14, 2011, respectively. For the first two experiments (east seep and middle seep), constant head was maintained in the trench with an average flow rate out of the trench of $5.8 \mathrm{~L} / \mathrm{min}$ at the beginning of the experiment and decreasing to $3.7 \mathrm{~L} / \mathrm{min}$ near the end of the experiment. The trench was not filled with water for the final two experiments on the west seep. Once toe material was removed and the pan installed, seepage began immediately without filling the trench. Actual seepage experiments started on March 18, 2011, and continued until March 20, 2011 (Table 1). Seepage occurred in three major locations, referred to as east seep (ES), middle seep (MS), and west seep (WS), as indicated in Fig. 1. Samples were collected from each of these seeps in one of the two methods described in the preceding subsections. 


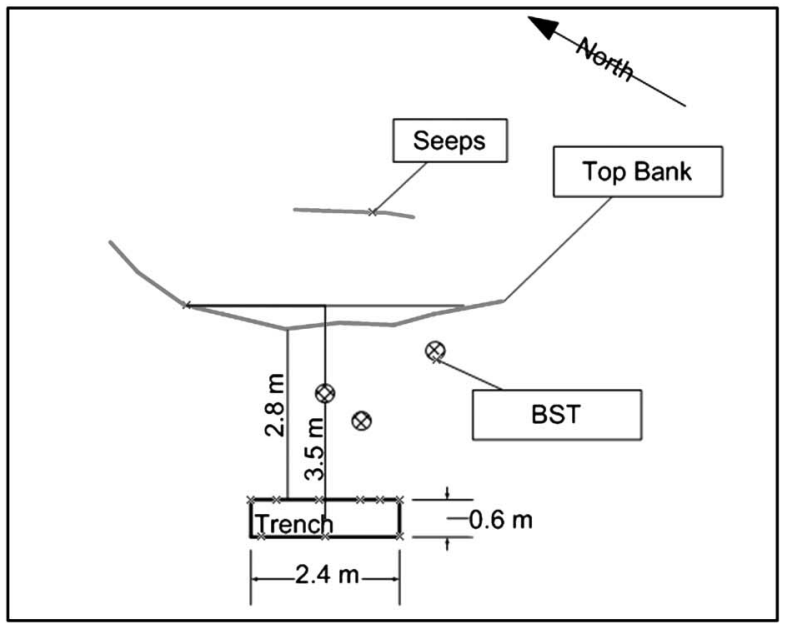

(a)

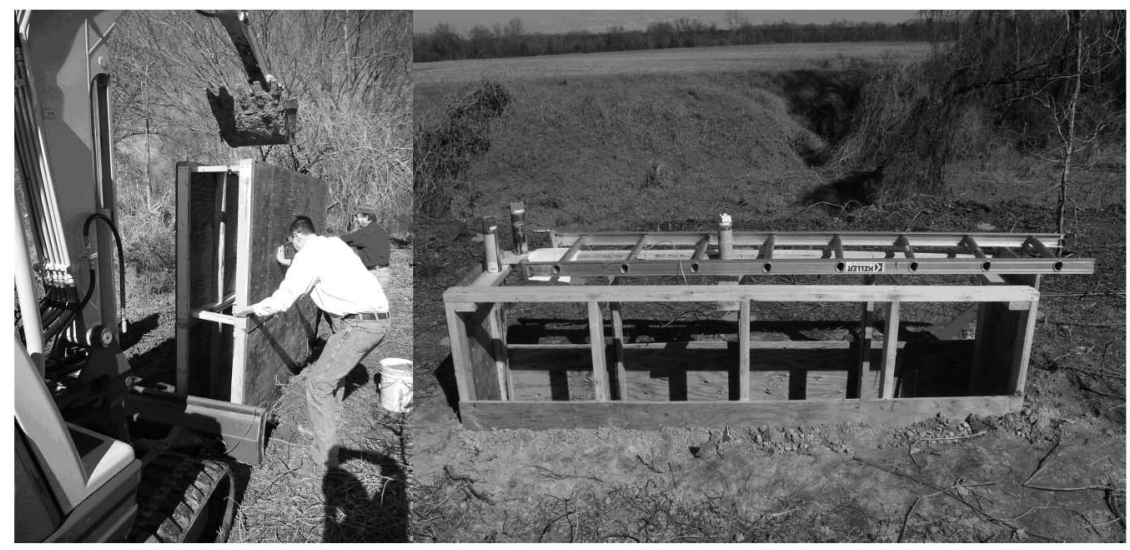

(b)

Fig. 2. (a) Trench location and dimensions relative to surveyed top bank profile (aerial view); locations of borehole shear tests are indicated; (b) trench frame installation for induced-seepage experiments; the trench was located $2.8 \mathrm{~m}$ from the bank face

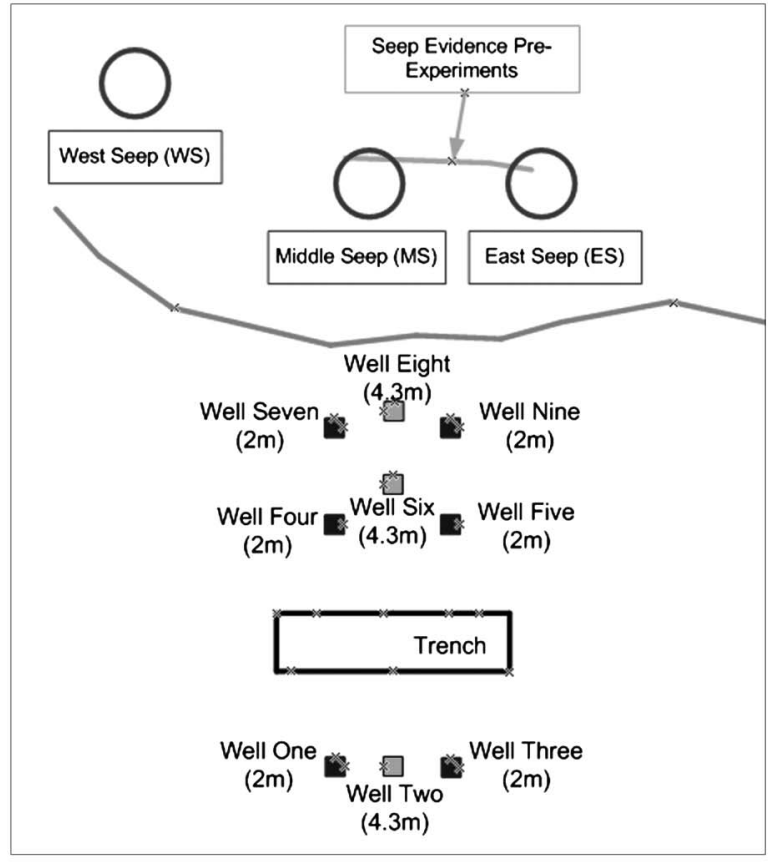

(a)

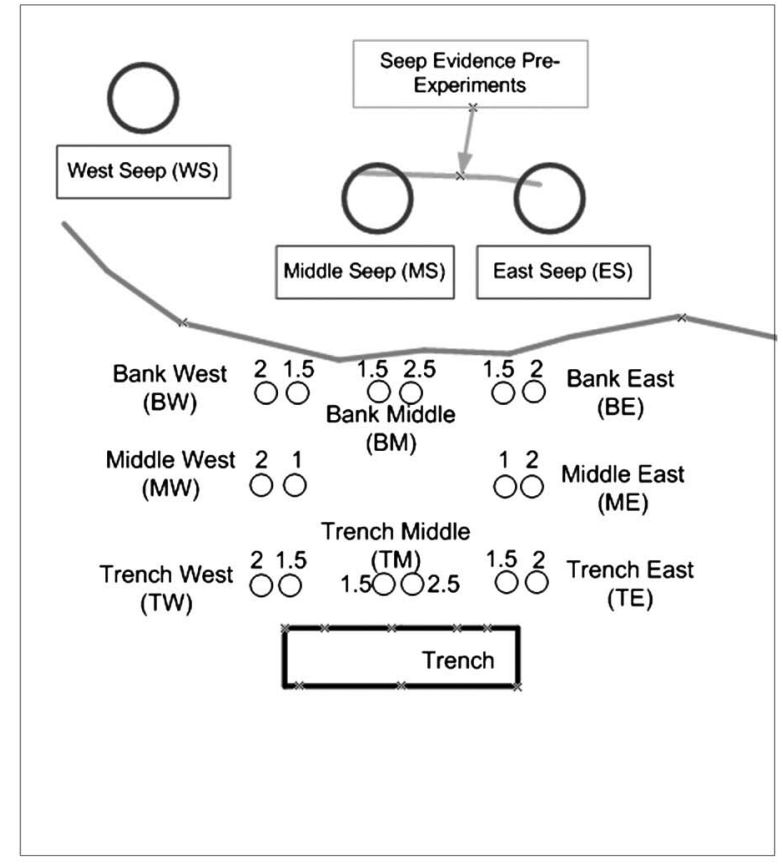

(b)

Fig. 3. (a) Well locations and depths relative to surveyed top bank profile (aerial view); (b) tensiometer locations where the number indicates the tensiometer depth in meters 
Table 1. Summary of Events and Experiments Conducted

\begin{tabular}{|c|c|c|c|}
\hline Experiment label & Description & Trench filled & End of constant head \\
\hline & Trench filled to prewet soil profile & March 15, 2011 at 11:10 a.m. & Allowed to drain \\
\hline & Trench filled to prewet soil profile & March 15, 2011 at $12: 30$ a.m. & Allowed to drain \\
\hline & Trench filled to prewet soil profile & March 16, 2011 at 11:20 a.m. & Allowed to drain \\
\hline Middle seep & Seepage experiment & March 18, 2011 at 11:20 a.m. & March 18, 2011 at 7:20 p.m. \\
\hline East seep & Seepage experiment & March 18, 2011 at 11:20 a.m. & March 18, 2011 at 7:20 p.m. \\
\hline West seep 1 & Seepage experiment & Trench not filled & - \\
\hline West seep 2 & Seepage experiment with eroded soil removed & Trench not filled & - \\
\hline
\end{tabular}

An experiment refers to a time period in which samples and data were collected from a given seep. Four seepage experiments were conducted: one on the east seep, one on the middle seep, and two on the west seep. Most experiments were started by filling and maintaining a constant head in the trench and by digging a vertical face at the seep location. Seepage would begin mobilizing the noncohesive sediment and would flow into the collection pan. After a seep experienced significant undercutting, failure would occur in the upper cohesive soil. For the second west seep experiment (WS2), failed materials and seeped materials were simultaneously collected separately as best as possible. For all other experiments, the failed material was allowed to accumulate in the pan or drain along with the seepage. Periodic measurements of the undercuts were recorded to monitor undercut growth. A light detection and ranging (LIDAR) scan (Topcon GLS-1,000 mass point collection, pulse-based laser scanner, Topcon, Livermore, CA) was acquired at the end of the experiments to investigate the shape of the seepage undercut with $1 \mathrm{~mm}$ resolution.

Seep flow versus erosion rates have been reported in the literature from one field study, and were suggested to follow an excess flow rate equation [i.e., Eq. (2) as proposed by Fox et al. 2007]. This excess flow rate equation mimicked an excess shear stress equation used for fluvial erosion. Data from all seeps were combined and linear regression analysis performed between the seep flow and erosion rates.

\section{Results and Discussion}

\section{Soil Properties}

In terms of bank stratigraphy, the authors observed that the loamy sand (seepage) layer was inclined, rising higher in elevation in the east direction along the bank face (Fig. 1). Because the seepage face in the west seep was lower in elevation than the east seep, the west seep had much higher flow rates and erosion rates, as discussed in a following section. Borehole shear tests illustrated the variability in streambank effective cohesion, $c^{\prime}$, and internal angle of friction, $\varphi^{\prime}$, with depth (Table 2). Similar to LTC streambanks (Wilson et al. 2007), the Dry Creek streambank consisted of a less cohesive loamy sand layer (approximately 3.0 to $3.5 \mathrm{~m}$ below ground surface, bgs) in between more cohesive loam layers (i.e., a clay loam 2.5 to $3.0 \mathrm{~m}$ bgs and a clay loam layer at $4.0 \mathrm{~m} \mathrm{bgs}$ and below). The borehole shear test data confirmed the presence of the loamy sand layer with apparent cohesions of $3.3 \mathrm{kPa}$ approximately 3.0 to $3.5 \mathrm{~m}$ below ground surface. Apparent cohesions in the clay loam layers above and below the seepage layer were 9.5 and $9.6 \mathrm{kPa}$, respectively (Table 2).

\section{Induced-Seepage Experiments}

The water surface elevation of the $2 \mathrm{~m}$ wells and the resulting contour plots developed using a kriging grid function in Surfer 8 indicated nonuniform flow in the shallow groundwater (Fig. 4). In this figure, $x$ is the distance from the northwest corner of trench $(x=0)$ running parallel to the trench and streambank and $y$ is the distance from northwest corner of trench $(y=0)$ running perpendicular to the trench and streambank. The trench was not filled for the water level contour map shown in Fig. 4(a), which resulted in a more confined east-west range compared to Figs. 4(b and c). Even the initial conditions prior to induced seepage on 3/15/11 indicated general flow to the west seep due to the recent precipitation events [Fig. 4(a)]. Well 9, a shallow groundwater well, was the most eastward well near the bank. This well varied by less than $0.10 \mathrm{~m}$ over the entire seepage tests (March 14, 2011 to March 22, 2011). On the other hand, well 7 (shallow groundwater well near the bank to the west) showed a strong response to the trench, varying by more than $0.6 \mathrm{~m}$ [Fig. 4(d)]. Three tensiometers at $1.5 \mathrm{~m}$ lined the bank (west: BW15, middle: BM15, and east: BE15). The westward tensiometer (BW15) had a greater response to the trench compared to the middle and east tensiometers (Fig. 5), indicating that the direction of primary flow was towards the northwest relative to the position of the tensiometers and observation wells.

Vector maps of the gradient developed from the water surface contour plots of the shallow wells confirmed this flow pattern and demonstrated fairly small gradients $(0.0$ to $0.2 \mathrm{~m} / \mathrm{m}$ on March 18 , 2011) on the east side of the trench near the streambank (east seep) and larger gradients $(0.2$ to $0.4 \mathrm{~m} / \mathrm{m}$ on March 18,2011$)$ near the middle seep. The increased gradient during the experimental period corresponded to the two-fold increase in seepage flow rate observed from the middle seep. Note that contour plots were limited

Table 2. Summary of Soil Type, Bulk Density, and Borehole Shear Test Results

\begin{tabular}{|c|c|c|c|c|c|c|c|}
\hline $\begin{array}{l}\text { Depth in } \\
\text { profile }^{\mathrm{a}}(\mathrm{m})\end{array}$ & Soil type ${ }^{b}$ & $\begin{array}{l}\text { Bulk density } \\
\qquad\left(\mathrm{g} \mathrm{cm}^{-3}\right)\end{array}$ & $\begin{array}{c}\text { Friction angle } \\
\text { (degrees) }\end{array}$ & $\begin{array}{c}\text { Matric } \\
\text { suction }(\mathrm{kPa})\end{array}$ & $\begin{array}{l}\text { Cohesion due to } \\
\text { matric suction }(\mathrm{kPa})\end{array}$ & $\begin{array}{c}\text { Effective } \\
\text { cohesion }(\mathrm{kPa})\end{array}$ & $\begin{array}{c}\text { Apparent } \\
\text { cohesion }(\mathrm{kPa})\end{array}$ \\
\hline $0.00-2.00$ & Clay loam & 1.58 & 19 & 5.5 & 1.0 & 8.6 & 9.5 \\
\hline $2.00-2.50$ & Sandy clay loam & 1.62 & 32 & 5 & 0.9 & 1.3 & 2.2 \\
\hline $2.50-3.50$ & Loamy sand & 1.55 & 29 & 0 & 0.0 & 3.3 & 3.3 \\
\hline $3.50-4.00$ & Clay loam & 1.53 & 21 & 0 & 0.0 & 9.6 & 9.6 \\
\hline
\end{tabular}

Note: Bulk density is an average of two samples. Borehole shear test shows single sample results.

${ }^{a}$ Depths represent an average profile. Stratigraphy varies because of sloping layers.

b Textural class determined by ASTM D422-63 (ASTM 2002) hydrometer analysis. 


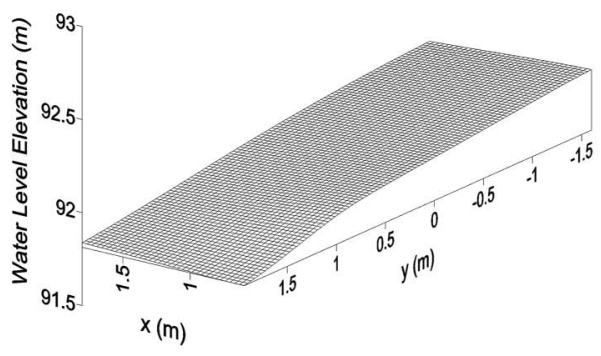

(a)

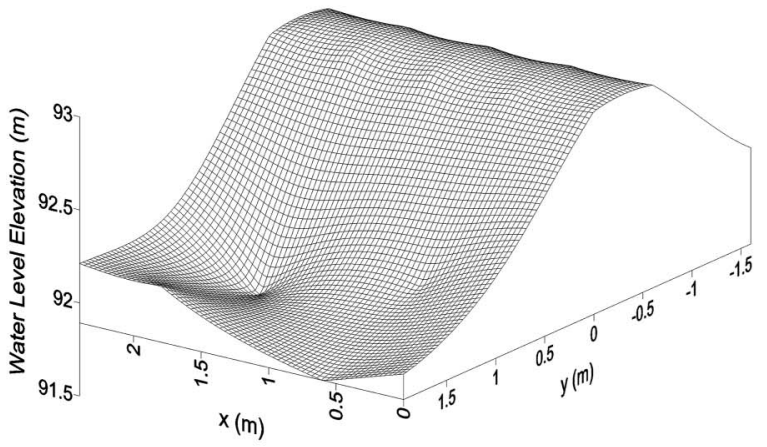

(b)

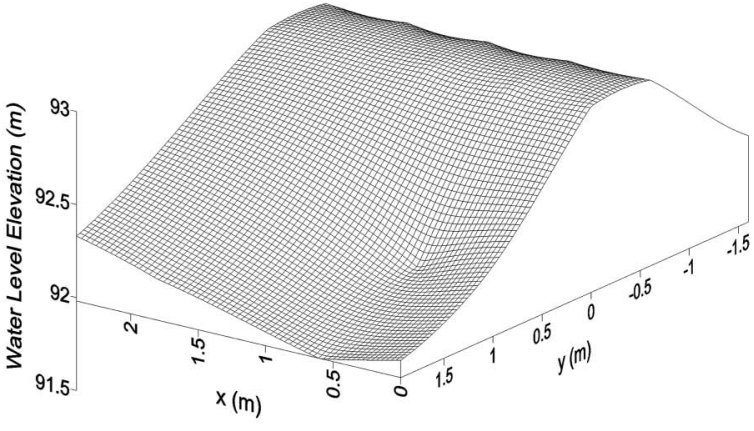

(c)

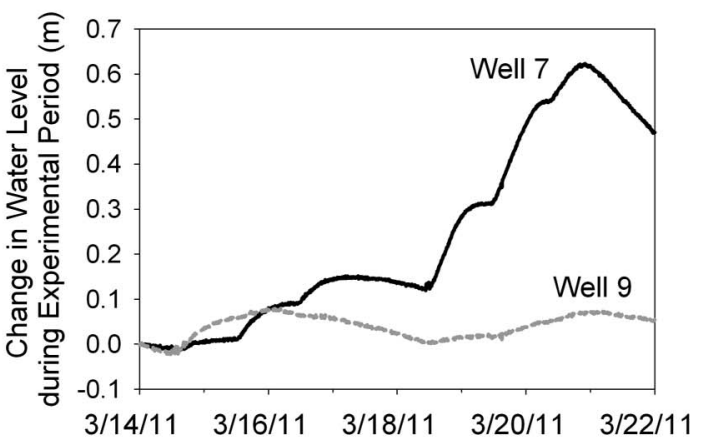

(d)

Fig. 4. Contour maps generated using Surfer 8 of groundwater surface elevations derived from the shallow groundwater wells prior to the seepage experiments on March 15, 2011: (a) at beginning of experiment; (b) during experiment; (c) end of the constant-head seepage for the east and middle seepage experiments on March 18,2011; (d) trends in water level change during the experimental condition in shallow groundwater wells 7 and 9 located near the streambank face

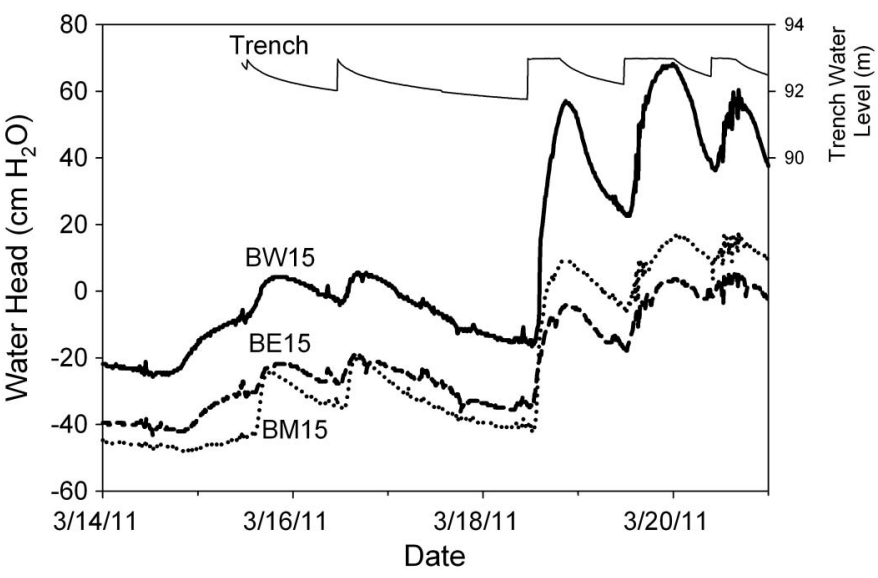

Fig. 5. Soil-water pressures of three $0.15-\mathrm{m}$ tensiometers located nearest the bank; BW15 had the greatest response to the trench as shown by the three peaks after March 18, 2011 along the edges of the boundary due to the lack of data in this region and therefore these gradient estimates are conservative. No gradients could be calculated near the west seep, although they are expected to mimic the middle seep due to the measured flow rates (Table 3). Water levels behind the trench were fairly uniform in the shallow groundwater wells (Fig. 4).

The deep 4.3-m wells also responded within an hour to establishing a head in the trench (Fig. 6). Well 2, located behind the trench away from the bank, showed a fast response and a high water surface, indicating that water was also moving into the field away from the bank. The fact that there was such a quick response between filling the trench and an increase in the pressure of the deep wells indicates much of the water was moving vertically below the trench to the conductive layer observed on the bank face (Fig. 1). As expected, the water pressure head was lower in the deep wells compared to the shallow wells due to the downward vertical flow.

The nonuniformity in flow paths and hydraulic gradients suggest difficulty when attempting to apply engineering analyses of bank stability for seepage processes. Attempts to link surface water 
Table 3. Overview of Flow and Erosion Rates of Each Experiment

\begin{tabular}{|c|c|c|c|c|c|}
\hline Experiment label & Description & $\begin{array}{l}\text { Maximum flowrate } \\
\text { (L/min) }\end{array}$ & $\begin{array}{l}\text { Average flowrate } \\
\text { (L/min) }\end{array}$ & $\begin{array}{l}\text { Maximum erosion } \\
\text { rate }(\mathrm{g} / \mathrm{min})\end{array}$ & $\begin{array}{l}\text { Average erosion } \\
\text { rate }(\mathrm{g} / \mathrm{min})\end{array}$ \\
\hline Middle seep & Seep was running, trench filled & 0.4 & 0.3 & 7.9 & 1.8 \\
\hline East seep & Trench filled and several hours later seep began & $<0.1$ & $<0.1$ & 0.13 & 0.06 \\
\hline West seep 1 & Trench not filled & 0.4 & 0.2 & 870 & 190 \\
\hline West seep $2^{\mathrm{a}}$ & Trench not filled & 2.2 & 1.4 & 6,900 & 4,200 \\
\hline
\end{tabular}

${ }^{a}$ West seep 2 is a special-case experiment where failed material (either seepage erosion or mass wasting) was removed immediately and counted toward the total erosion rates shown.

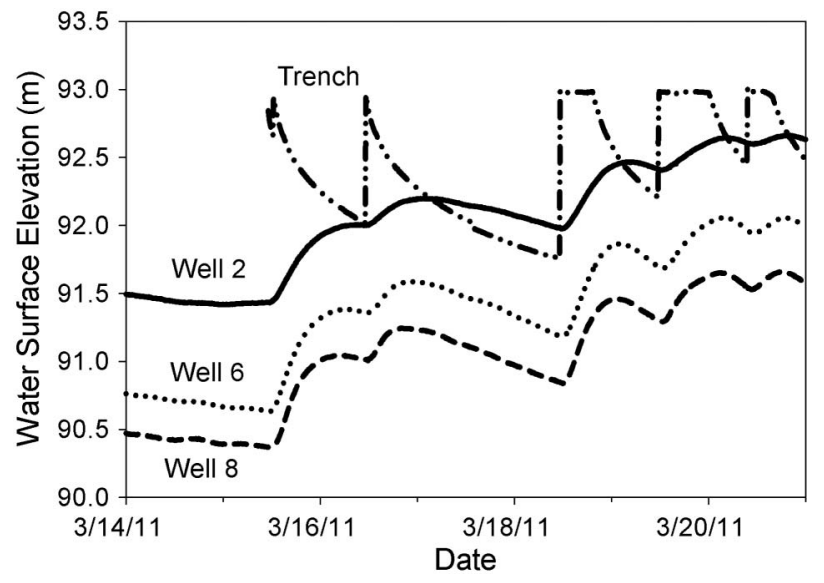

Fig. 6. Water surface elevation of trench and water pressures in the 4.3-m wells during the induced-seepage experiments

and groundwater flow models (e.g., He et al. 2008; Bansal and Das 2009) with streambank stability models (Rinaldi et al. 2008) must consider local-scale heterogeneity associated with bank stratigraphy and soil layering. Also, water levels during the induced-seepage experiment were similar (within $0.5 \mathrm{~m}$ ) to water level observations in the groundwater wells made shortly after precipitation events on March 4-5, 2011. Wetter conditions could easily achieve the hydraulic heads observed in the well field. Natural rainfall events lead to saturation of the bank profile through both infiltrated water upslope and return of banked stored water after high stream stages (Hunt 2005). While the trench induced similar hydraulic gradients on the shallow groundwater system, precipitation leading to high flow events also results in wetting of the cohesive clay layer above the seeps, decreasing the stability of the streambank. This wetting up of the cohesive soil layer above the seep was not simulated with the constant-head trench experiment until infiltrated water reached the streambank.

Table 3 provides an overview of the individual seep experiments and their maximum flow and erosion rates. The general method of failure was observed to be seepage of underlying noncohesive sand followed by mass failure of cohesive soil above. Seepage erosion and pop-out failures due to seepage gradient forces were both observed to be dominating forces of erosion in the sand layer. Generally, soil-water pressures of the upper cohesive material would also increase as indicated by tensiometers, thereby increasing the weight and reducing the apparent cohesion of the soil and eventually triggering a mass failure event.

Each experiment described in the following discussion would start with a clean vertical face (Table 3 ). As the sand eroded and cohesive material collapsed, it would be more difficult for the seepage to pass through/around the failed cohesive blocks, thus creating a flow and erosion restriction. This self-healing process has been observed on streambanks experiencing mass wasting, whereby failed material protects the base of the bank until fluvial processes remove it, referred to as basal endpoint control (Carson and Kirkby 1972; Thorne and Tovey 1981; Thorne 1982; Pizzuto et al. 2007). Subsequent fluvial erosion renews the banks for erosion by other processes, creating a cyclical pattern in bank failure events. This observation for a specific seepage cut on in situ streambanks is unique to this research. Fox et al. (2006) reported from laboratory experiments that seepage erosion and fluvial erosion must be linked, or the accumulated sediment from seepage erosion and subsequent mass failure would block continued seepage erosion if fluvial erosion did not remove the failed material. The second experiment on the west seep (WS2) simulated this process of removal by fluvial erosion by manually removing all failed material. Such action greatly increased the erosion rate and growth in size of the undercut. This documents the importance of seepage erosion acting in concert with fluvial forces. The power of the self-healing process can be demonstrated in the undercut growth of the various seepage experiments. In the middle seep, undercut growth was $10 \mathrm{~cm}$ over $8 \mathrm{~h}$. This is after the initial formation of a $30-\mathrm{cm}$ undercut before sampling began. The WS1 experiment experienced much faster growth (38 cm in depth over $51 \mathrm{~min})$. These experiments were characterized by initial rapid undercut growth then slowed due to the self-healing. The experiment for the west seep, in which failed material was removed (WS2), experienced $91 \mathrm{~cm}$ of growth in just $40 \mathrm{~min}$. Subsequent sections provide more details on the specific seep experiments.

\section{Middle Seep Experiment}

The middle seep was observed to be flowing several days before the experiment due to a high water table caused by rain events combined with filling of the trench to prewet the bank. This seep occurred at a midlevel elevation relative to the position of the loamy sand layer on the streambank (Fig. 1). Contour plots of the water surface elevations in the shallow groundwater wells indicated an initial gradient of $0.2 \mathrm{~m} / \mathrm{m}$ prior to filling the trench on March 18th (Fig. 4). The trench was filled and samples were collected at 11:20 on the morning of March 18, 2011. The trench head was held constant at $1.4 \mathrm{~m}$ for eight $\mathrm{h}$ once filled and hydraulic gradients responded to this induced head, increasing to approximately $0.4 \mathrm{~m} / \mathrm{m}$ by the end of the constant-head period. As noted in Eq. (1), seepage forces exerted on the soil are proportional to the hydraulic gradient. At the beginning of monitoring seepage flow and erosion, a vertical face was created at the seepage location. Flow rates started at $0.21 \mathrm{~L} / \mathrm{min}$ and increased to $0.42 \mathrm{~L} / \mathrm{min}$ (Fig. 7), matching the observed patterns in the hydraulic gradients derived from the water surface contour maps (Fig. 4). Erosion rates also appeared to slightly increase with time. There were two observations $(5.35 \mathrm{~g} / \mathrm{min}$ and $7.85 \mathrm{~g} / \mathrm{min})$ which seemed to fall outside the general increasing erosion rate trend between $0.81 \mathrm{~g} / \mathrm{min}$ to $2.57 \mathrm{~g} / \mathrm{min}$ (Fig. 7). These points occurred shortly after larger blocks of failed material liquefied and flowed into the collection pipe. After $8 \mathrm{~h}$, the collection pan became overwhelmed with material blocking further particle mobilization. 


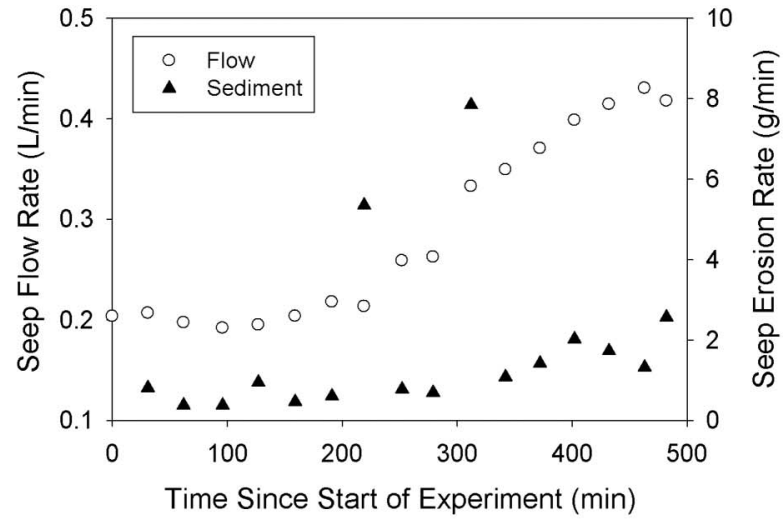

(a)

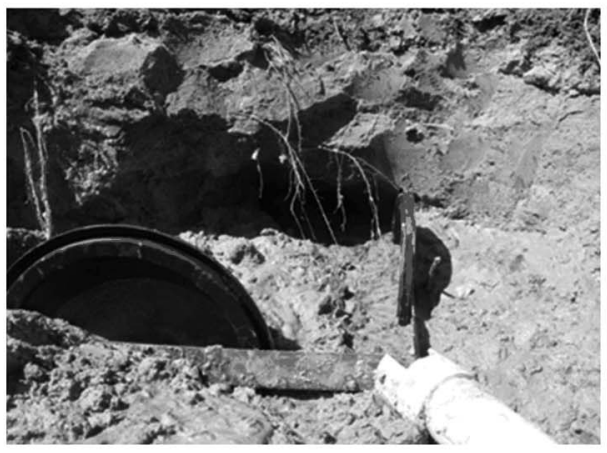

(b)

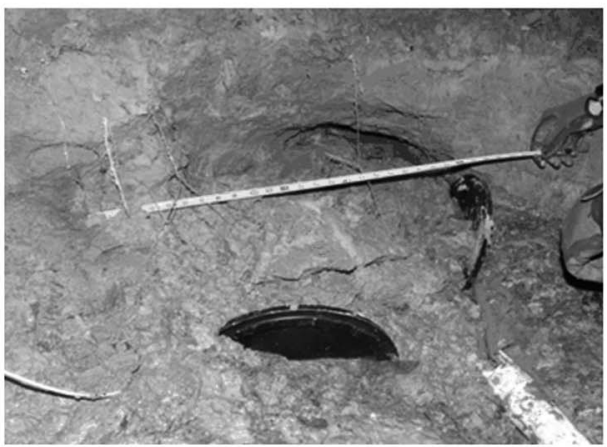

(c)

Fig. 7. (a) Seepage flow and erosion rates versus time after initiation of a hydraulic head in the trench on the middle seep; (b) middle seep near beginning of experiment; (c) middle seep near end of experiment

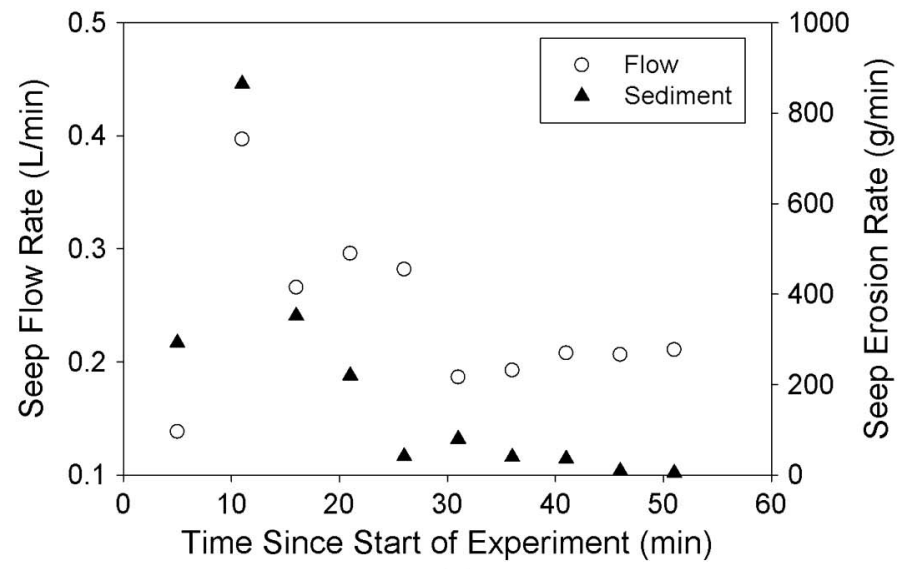

(a)

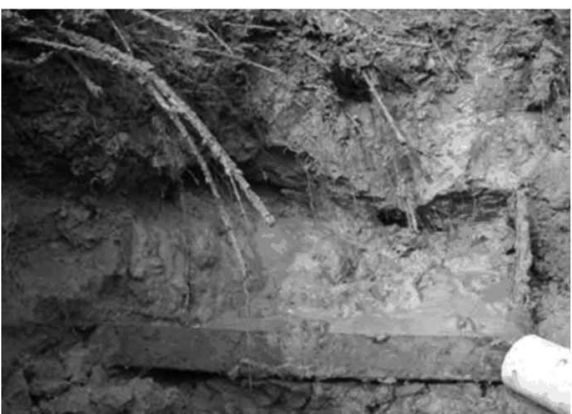

(b)

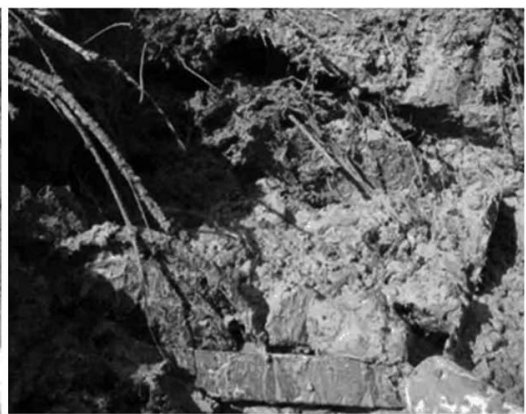

(c)

Fig. 8. (a) Flow and erosion rates versus time for WS1 (material allowed to remain in the collection flume) on the left streambank seep; (b) WS1 near beginning of experiment; (c) WS1 near end of experiment 


\section{East Seep Experiment}

This was a low flow seep location due to the hydraulic gradients established in the near-bank region of the soil profile (Fig. 4). Contour plots and gradients indicated nonuniform flow away from this seep most likely due to the sloping stratigraphy of the loamy sand layer in which the seeps originated. The east seep was at the upper end of this sloping conductive layer. Seepage gradients estimated from the contour maps were initially near zero when the trench was filled on March 18, 2011, and slowly increased to approximately $0.2 \mathrm{~m} / \mathrm{m}$ at the end of the constant-head experiment. In fact, the east seep did not exhibit flow until $5 \mathrm{~h}$ into the experiment, matching the observation of the initial seepage gradients. This location was setup similar to the middle seep with a vertical shear face and collection pan installed. Flow rates slowly increased from $0.004 \mathrm{~L} / \mathrm{min}$ to $0.006 \mathrm{~L} / \mathrm{min}$ and erosion rates varied between $0.015 \mathrm{~g} / \mathrm{min}$ and $0.134 \mathrm{~g} / \mathrm{min}$.

\section{West Seep Experiments}

The west seep was located at a lower elevation than the other seeps in the loamy sand layer (Fig. 1). This seep was outside the domain of the water surface contour maps, but most likely experienced similar hydraulic gradients to the middle seep (Fig. 4) due to the similar flow rates observed during the experiments. Once toe material was removed and the pan installed, seepage began immediately in this location without filling the trench (Fig. 8). Sampling of this seep occurred for $51 \mathrm{~min}$ when the collection pan became overwhelmed with cohesive material blocking further particle mobilization (Fig. 8). Flow rates were typically between 0.2 and $0.3 \mathrm{~L} / \mathrm{min}$ with erosion rates peaking at greater than $800 \mathrm{~g} / \mathrm{min}$, again most likely due to a small-scale failure in the seepage undercut formation.

The second experiment on the west seepage location attempted to separate the seeped material from the mass failure material as efficiently as possible, essentially removing the restriction created by the failed block materials of the previous experiments. This resulted in high erosion rates creating a deep cavity (approximately $1 \mathrm{~m}$ ) within $42 \mathrm{~min}$. In response to removal of failed material, seepage flow rates increased between 2.0 and $3.0 \mathrm{~L} / \mathrm{min}$ due to rapid growth of the undercut and potentially increasing convergence of seep flow paths. Erosion rates were orders of magnitude higher when self-healing was prevented, and interestingly, seepage erosion rates were on the same order of magnitude as erosion rates by mass wasting (Fig. 9). Peaks in the mass wasting sediment concentrations corresponded to times when the walls of the seepage undercut collapsed (Fig. 9). Dimensions of the seepage undercut at the end of the experiment were $91 \mathrm{~cm}$ wide, $43 \mathrm{~cm}$ tall, and extended $91 \mathrm{~cm}$ into the bank face [Fig. 9(b)] with a shape similar to
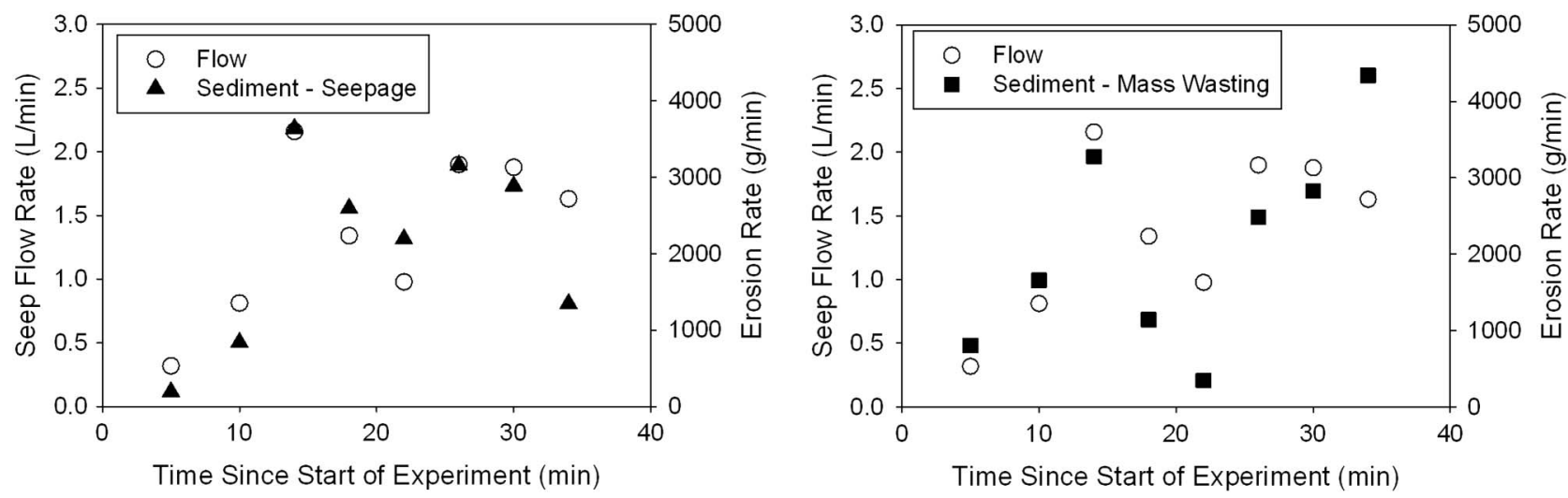

(a)

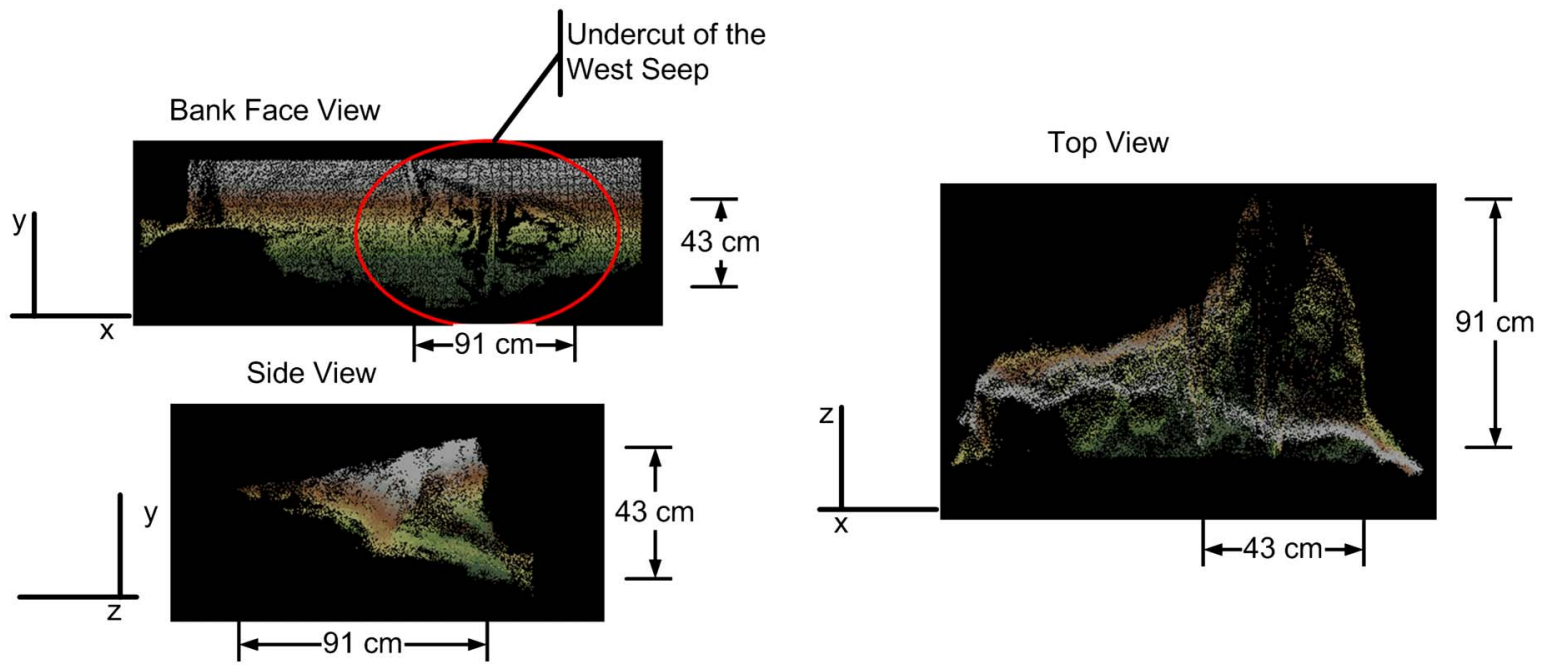

(b)

Fig. 9. (a) Seepage flow and erosion (seepage on left and mass wasting on right) rates over time for experiment two on the west seep, WS2 (sediment and mass wasting material removed from collection flume) on the right seep; (b) LIDAR images of the seepage undercut at the end of the WS2 experiment. Coordinate directions $x$ and $y$ are horizontally and vertically along the bank face, and $z$ is oriented perpendicular to the bank with positive direction into the bank. Shading indicates variation in elevation above mean sea level 


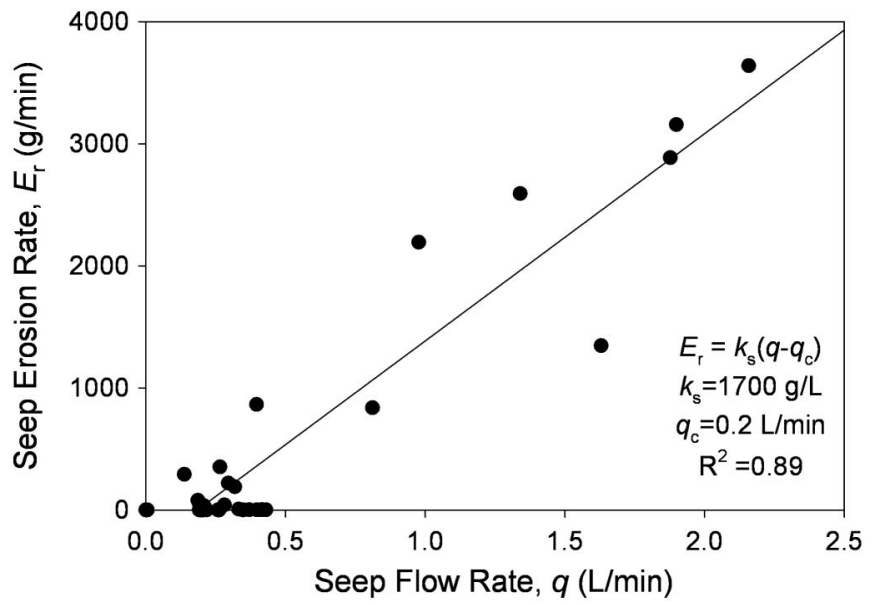

Fig. 10. Relationship between seepage flow rate and seepage erosion rate observed during the induced-seepage experiments. The linear regression was developed using data from all three seep locations (east, middle, and west)

but not as uniform as undercuts observed in laboratory experiments by Chu-Agor et al. (2008a). The lack of uniformity in the undercut shape was likely due heterogeneity in the soil properties and the presence of roots decreasing erodibility and increasing stability.

\section{Seep Flow Rate versus Erosion Rate}

Combining data from all the Dry Creek seeps provided a similar relationship to that observed by Fox et al. (2007). In fact, the critical seep flow rate or discharge was similar between the studies $\left(q_{c}=0.2 \mathrm{~L} / \mathrm{min}\right)$, as shown in Fig. 10. Unique seepage erosion rate coefficients, $k_{s}$, were observed due to differences in soil type: $k_{s}$ of approximately $1,700 \mathrm{~g} / \mathrm{L}$ in this experiment on loamy sand versus $k_{s}$ of $70 \mathrm{~g} / \mathrm{L}$ on sandy loam (Fox et al. 2007). Note the variation in observed seepage erosion rates near the critical seep flow rate, which is a similar phenomenon observed for fluvial erosion rates measured by jet erosion tests. With that said, this research further supports the validity of Eq. (2) in modeling seepage erosion transport rates for undercut predictions in the field.

\section{Summary and Conclusions}

Limited work has been conducted in the field to observe and quantify seepage mechanisms of erosion and bank failure under controlled conditions. To fill this gap, this research provided an innovative investigation into seepage flow and erosion measurements and mechanisms through the use of a trench injection system installed near a streambank face along Dry Creek in northern Mississippi. Seepage from the trench injections rapidly mobilized particles from a loamy sand layer resulting in undercutting and instability in cohesive material above the seep. Seepage erosion of the loamy sand layer was the dominate mechanism removing sediment from the bank, leading to failure of consolidated blocks of the material above the seepage undercut.

Mass failure of material around seepage undercuts was shown to limit the continuation of seepage erosion providing temporary selfhealing of the bank. When these failures involved noncohesive material, seepage was able to entrain particles, and restrictions to the flow and erosion were temporary. However, when mass failure involved cohesive material, seepage flow rates and seepage erosion became severely limited. Unless seepage flow rates or fluvial erosion were sufficient to remove the sloughed sediment, seepage erosion would not continue. Such self-healing followed by block removal can lead to a cyclical pattern of bank retreat where failed bank material provides bank toe protection relative to hydraulic stresses until fluvial erosion restores the bank for seepage erosion mass failure.

These data and analyses indicate that seepage erosion can be a dominate factor for streambank erosion when linked with fluvial erosion to remove the displaced sediment. For seepage erosion to continue apart from fluvial erosion, there must be enough force from the seepage flow to remove the cohesive capping material or occur where there is no upper layer of cohesive material to block the seeps. The relationship between seepage flow rate and erosion rate did follow an excess flow rate formulation as reported in the only previous streambank seepage field study. Seepage flow rates were proportional to estimated hydraulic gradients in the nearstreambank region; however, flow paths and hydraulic gradients were largely nonuniform, suggesting difficulty when attempting to apply engineering analyses of bank stability for seepage processes. Attempts to link groundwater flow models with streambank stability models must consider local-scale heterogeneity associated with bank stratigraphy and soil layering. Potentially, seepage analyses for bank stability assessment should focus on the most critical locations on the bank face, where seepage gradients and flow paths converge. Nonintrusive remote sensing techniques are needed. Current research is underway investigating the effect of seepage gradients on the fluvial erodibility coefficient of soil, which could be a factor in many of these cases, and future work is planned to further ascertain linkages between fluvial and seepage erosion processes.

\section{Acknowledgments}

The authors wish to thank the technical support personnel (Mick Ursic, Don Seale, Alan Hudsped, Allen Gregory, and Brian Bell) at the National Sedimentation Laboratory in Oxford, Mississippi for assistance with instrumentation and data collection for this project. This material is based upon work supported by the National Science Foundation (NSF) under Grant No. 0943491. Any opinions, findings, and conclusions or recommendations expressed in this material are those of the authors and do not necessarily reflect the views of the National Science Foundation.

\section{References}

ASCE Task Committee on Hydraulics, Bank Mechanics, and Modeling of River Width Adjustment. (1998). "River width adjustment. I: Processes and mechanisms." J. Hydraul. Eng., 124(9), 881-902.

ASTM. (2002). "Standard test method for particle size analyses of soils." D422-63, ASTM International.

Bansal, R. K., and Das, S. K. (2009). "Effects of bed slope on water head and flow rate at the interfaces between the stream and groundwater: Analytical study." J. Hydrol. Eng., 14(8), 832-838.

Carson, M. A., and Kirkby, M. J. (1972). Hillslope form and process, Cambridge University Press, Cambridge, UK.

Chu-Agor, M. L., Fox, G. A., Cancienne, R. M., and Wilson, G. V. (2008a). "Seepage caused tension failures and erosion undercutting of hillslopes." J. Hydrol., 359(3-4), 247-259.

Chu-Agor, M. L., Wilson, G. V., and Fox, G. A. (2008b). "Numerical modeling of bank instability by seepage erosion undercutting of layered streambanks." J. Hydrol. Eng., 13(12), 1133-1145.

Evans, D. J., Gibson, C. E., and Rossell, R. S. (2006). "Sediment loads and sources in heavily modified Irish catchments: A move towards informed management strategies." Geomorphology, 79(1-2), 93-113. 
Fox, G. A., and Wilson, G. V. (2010). "The role of subsurface flow in hillslope and streambank erosion: A review." Soil Sci. Soc. Am. J., 74(3), 717-733.

Fox, G. A., Wilson, G. V., Periketi, R. K., and Cullum, R. F. (2006). "Sediment transport model for seepage erosion of streambank sediment." J. Hydrol. Eng., 11(6), 603-611.

Fox, G. A., Wilson, G. V., Simon, A., Langendoen, E. J., Akay, O., and Fuchs, J. W. (2007). "Measuring streambank erosion due to groundwater seepage: Correlation to bank pore water pressure, precipitation and stream stage." Earth Surf. Processes Landforms, 32(10), 447-459.

Fredlund, D. G., and Rahardjo, H. (1993). Soil mechanics for unsaturated soils, Wiley, New York.

Hagerty, D. J. (1991). "Piping/sapping erosion. 1: Basic considerations." J. Hydraul. Eng., 117(8), 991-1008.

Hagerty, D. J., Spoor, M. F., and Ullrich, C. R. (1981). "Bank failure and erosion on the Ohio River." Eng. Geol., 17(3), 141-158.

He, Z., Wu, W., and Wang, S. S. Y. (2008). "Coupled finite-volume model for 2D surface and 3D subsurface flows." J. Hydrol. Eng., 13(9), 835-845.

Hunt, B. (2005). "Bank-storage problem and the Dupuit approximation." J. Hydrol. Eng., 10(2), 118-124.

Iverson, R. M., and Major, J. J. (1986). "Groundwater seepage vectors and the potential for hillslope failure and debris flow mobilization." Water Resour. Res., 22(11), 1543-1548.

Lawler, D. M., Thorne, C. R., and Hooke, J. M. (1997). "Bank erosion and instability." Applied fluvial geomorphology for river engineering and management, C. R. Thorne, R. D. Hey, and M. D. Newson, eds., Wiley, New York, 137-172.

Lobkovsky, A. E., Jensen, B., Kudrolli, A., and Rothman, D. H. (2004). "Threshold phenomena in erosion driven by subsurface flow." J. Geophys. Res., 109(F4), F04010.

Pizzuto, J. E., et al. (2007). "Streambank erosion and river width adjustment." Sedimentation engineering: Processes, measurements, modeling and practice, M. H. Garcia, ed., ASCE, Reston, VA, 387-438.

Richards, K. S., and Reddy, K. R. (2007). "Critical appraisal of piping phenomena in earth dams." Bull. Eng. Geol. Environ., 66(4), 381-402.

Rinaldi, M., Casagli, N., Dapporto, S., and Gargini, A. (2004). "Monitoring and modelling of pore water pressure changes and riverbank stability during flow events." Earth Surf. Processes Landforms, 29(2), 237-254.
Rinaldi, M., Mengoni, B., Luppi, L., Darby, S. E., and Mosselman, E. (2008). "Numerical simulation of hydrodynamics and bank erosion in a river bend." Water Resour. Res., 44(9), W09428.

Rulon, J. J., Rodway, R., and Freeze, R. A. (1985). "The development of multiple seepage faces on layered slopes.” Water Resour. Res., 21(11), $1625-1636$.

Sekely, A. C., Mulla, D. J., and Bauer, D. W. (2002). "Streambank slumping and its contribution to the phosphorus and suspended sediment loads of the Blue Earth River, Minnesota." J. Soil Water Conserv., 57(5), 243-250.

Simon, A. (1995). "Adjustment and recovery of unstable alluvial channels: Identification and approaches for engineering management." Earth Surf. Processes Landforms, 20(7), 611-628.

Simon, A., Curini, A., Darby, S. E., and Langendoen, E. J. (2000). "Bank and near-bank processes in an incised channel." Geomorphology, 35(3-4), 183-217.

Simon, A., and Darby, S. E. (1999). "The nature and significance of incised river channels." Incised river channels: Processes, forms, engineering and management, S. E. Darby and A. Simon, eds., Wiley, Chichester, UK.

Soenksen, P. J., Turner, M. J., Dietsch, B. J., and Simon, A. (2003). "Stream bank stability in eastern Nebraska." Water Resources Investigations Rep. 03-4265, U.S. Geological Survey, Denver, CO.

Surfer 8, version 8.09 [Computer software]. Golden Software Inc., Golden, $\mathrm{CO}$.

Thorne, C. R. (1982). "Processes and mechanisms of river bank erosion." Gravel-bed rivers, R. D. Hey, J. C. Bathurst, and C. R. Thorne, eds., Wiley, Chichester, UK, 227-271.

Thorne, C. R., and Tovey, N. K. (1981). "Stability of composite river banks." Earth Surf. Processes Landforms, 6(5), 469-484.

Wilson, C. G., et al. (2008). "Quantifying relative contributions from sediment sources in conservation effects assessment project watersheds." J. Soil Water Conserv., 63(6), 523-531.

Wilson, G. V., Nieber, J., Sidle, R. C., and Fox, G. A. (2013). "Internal erosion during soil pipeflow: State of the science for experimental and numerical analysis." Trans. ASABE, 56(2), 465-478.

Wilson, G. V., Periketi, R., Fox, G. A., Dabney, S. M., Shields, F. D., and Cullum, R. F. (2007). "Soil properties controlling seepage erosion contributions to streambank failure." Earth Surf. Processes Landforms, 32(3), 447-459. 